\title{
PELAKSANAAN PERATURAN DAERAH KABUPATEN JENEPONTO NOMOR 8 TAHUN 2006 TENTANG LARANGAN PEREDARAN MINUMAN BERALKOHOL DAN PENGAWASANNYA DI KECAMATAN BINAMU KABUPATEN JENEPONTO
}

\author{
Oleh
}

\author{
ANDI KASMAWATI \\ BAKHTIAR \\ NURHAYATI
}

\begin{abstract}
Dosen PPKn FIS UNM
ABSTRAK: Penelitian ini bertujuan untuk mengetahui: (1) Pelaksanaan Peraturan Daerah Kabupaten Jeneponto Nomor 8 Tahun 2006, (2) Faktor pendukung dan penghambat Pelaksanaan Peraturan Daerah Kabupaten Jeneponto Nomor 8 Tahun 2006. Penelitian ini merupakan penelitian deskriptif kualitatif. Adapun prosedur pengumpulan data yang digunakan adalah wawancara dan dokumentasi. Sedangkan analisis data yang digunakan adalah analisis kualitatif. Dari hasil penelitian menunjukkan bahwa Pelaksanaan Peraturan Daerah Kabupatenn Jeneponto Nomor 8 Tahun 2006 belum berjalan secara efektif, hal ini di sebabkan karena masih banyaknya minuman beralkohol yang beredar di masyarakat yang bisa di dapat di toko - toko dan rumah warga serta kurangnya pengetahuan masyarakat akan keberadaan dari perda tersebut. Adapun yang menjadi faktor pendukung dari Pelaksanaan Peraturan Daerah Kabupaten Jeneponto Nomor 8 Tahun 2006 ialah: (1) Partisipasi tokoh agama dan masyarakat, (2) kerjasama antar aparat pemerintah. Sedangkan yang menjadi faktor penghambat Pelaksanaan Peraturan Daerah Kabupaten Jeneponto Nomor 8 Tahun 2006 diantaranya: (1) faktor kesadaran, (2) faktor sosialisasi, (3) faktor pemberian sanksi (4) faktor kebiasaan, (5) tindak lanjut dari pelanggaran Perda No. 8 tahun 2006 masih dalam tahap non yuspisial yaitu tidak adanya penyelidikan dan penyidikan di bagian satuan polisi pamong praja.
\end{abstract}

\section{Kata Kunci: Larangan Peredaran Minuman Beralkohol dan Pengawasannya}

\begin{abstract}
This study aims to determine: (1) Implementation Jeneponto District Regulation No. 8 of 2006, (2) supporting and inhibiting factors Implementation Jeneponto District Regulation No. 8 of 2006. This study is a qualitative descriptive study. The data collection procedures used were interviews and documentation. While data analysis used is qualitative analysis. The results showed that the implementation of the Regional Regulation Kabupatenn Jeneponto No. 8 of 2006 does not operate effectively, this is caused because there are many alcoholic drinks that circulate in the community who can be in stores - stores and houses as well as a lack of public awareness of the existence of these regulations. The supporting factors of Implementation Jeneponto District Regulation No. 8 of 2006 are: (1) Participation of community and religious leaders, (2) cooperation among government officials. While the factors that inhibit the implementation of Jeneponto District Regulation No. 8 of 2006 include: (1) the awareness factor, (2) socialization factors, (3) factors sanctions (4) that habit, (5) follow-up of violations of Bylaw No. 8 in 2006 is still in the stage of non yuspisial namely the lack of investigations and inquiries at the police forces of the civil service.
\end{abstract}

Keywords: Prohibition of Circulation of Alcoholic Beverages and Supervision 


\section{PENDAHULUAN}

Otonomi Daerah merupakan tema lama yang tampaknya selalu menemukan aktualitas dan relevansinya. Di katakan tema lama, karena Undang - Undan Dasar 1945 telah memberikan landasan yuridis yang jelas tentang eksistensi otonomi daerah. Sampai saat ini, sudah enam kali diadakan perubahan atau penyempurnaan. Terakhir dengan Undang Undang Nomor 22 Tahun 1999 (akan di sempurnakan lagi sesuai Ketetapan MPR Nomor IV Tahun 2000), merupakan Undang Undang ketujuh yang mengatur tentang otonomi daerah.

Sama halnya dengan Daerah Kabupaten Jeneponto dalam mengurus sendiri urusan daerahnya membuat suatu peraturan daerah. Salah satu peraturan daerah tersebut adalah Peraturan Daerah Nomor 8 Tahun 2006 Tentang Larangan Peredaran Minuman Beralkohol dan Pengawasannya. Peraturan tersebut di buat untuk mengawasi peredaran minuman beralkohol yang ada di Daerah Kabupaten Jeneponto mengingat daerah Jeneponto sangat terkenal dengan minuman tradisional atau masyarakat mengenalnya dengan nama Ballo (Tuak). Penyalahgunaan dan peredaran minuman beralkohol yang tidak terkendali dapat menimbulkan semakin meningkatnya tindak kejahatan akibat meminum minuman beralkohol yang dapat mengganggu ketentraman dan ketertiban masyarakat. Untuk mengatasi permasalahan tersebut di perlukan adanya Pengawasan dan pengendalian terhadap peredaran dan penjualan minuman beralkohol di Kabupaten Jeneponto. Peredaran minuman beralkohol jenis Ballo (tuak) di kalangan masyarakat seolah - olah merupakan hal yang biasa karena minuman beralkohol jenis ballo (tuak) sudah menjadi kebiasaan untuk di konsumsi oleh masyarakat sehingga sulit untuk di atasi.

Khususnya di Kecamatan Binamu peredaran minuman beralkohol jenis ballo (tuak) beredar luas karena minuman beralkohol jenis ballo (tuak) ini sangat di gemari oleh kalangan masyarakat mulai dari remaja, dewasa dan orang tua,penjualan minuman beralkohol jenis ballo (tuak) ini biasa di jual di rumah sendiri, masyarakat sendiri sudah terbiasa dengan peredaran tersebut. sehingga sangat meresahkan masyarakat,ini di rasakan dengan terganggunya ketentraman dan kenyamanan masyarakat. Pada malam hari biasanya para remajaberkumpul untuk meminum minuman beralkohol sehingga tak jarang keributan pun terjadi di mana para remaja biasanya terlibat perkelahian yang di lakukan oleh remaja - remaja yang sudah terpengaruh dengan minuman beralkohol. Mereka juga selalu berbuat ulah mulai dari menyalakan motor dengan suara yang sangat keras dan balap - balapan sehingga sangat mengganggu ketentraman dan kenyamanan masyarakat. Dalam meminum minuman beralkohol para remaja berkumpul di sebuah tempat yang biasa jadi tempat mereka untuk meminum minuman beralkohol sehingga perlu adanya pengaturan terkait dengan pengendalian melalui suatu perizinan karena apabila hal tersebut terus terjadi maka itu akan merusak masa depan anak - anak sehingga di perlukan suatu penanganan yang bisa mengatasi permasalahan tersebut. dengan semakin meningkatnya tindak pidana kejahatan sebagai akibat meminum minuman beralkohol yang dapat mengganggu ketentraman masyarakat perlu mengatur Larangan Peredaran Minuman Beralkohol dan Pengawasannya sehingga di buatlah suatu Peraturan Daerah Nomor 8 tahun 2006. Mengingat keputusan Presiden Nomor 3 Tahun 1997 tentang Pengawasan dan Pengendalian Minuman Beralkohol dan Peraturan Menteri Perdagangan Republik Indonesia Nomor : 43/MDAG/PER/9/2009 Tentang Pengadaan, Pengedaran, Penjualan, Pengawasan, dan Pengendalian Minuman Beralkohol.

Pengawasan dan pengendalian adalah segala usaha atau kegiatan untuk mengetahui, menilai dan mengarahkan agar peredaran minuman beralkohol dapat di laksanakan sesuai ketentuan peraturan perundang - undangan yang berlaku. Hal ini sebenarnya dilakukan untuk membatasi peredaran minuman keras. Dengan adanya peraturan daerah tersebut di harapkan dapat menjadi alat untuk mengontrol dan mengatasi peredaran minuman beralkohol jenis ballo (tuak) dan membawa pengaruh yang 
baik terhadap masyarakat untuk tidak mengkonsumsi minuman tersebut dan mematuhi peraturan yang ada.

Penyalahgunaan minuman keras saat ini merupakan permasalahan yang cukup berkembang di dunia remaja dan menunjukkan kecenderungan yang meningkat dari tahun ke tahun, yang akibatnya di rasakan dalam bentuk kenakalan - kenakalan, perkelahian, munculnya geng - geng remaja, perbuatan asusila dan maraknya premanisme pada kalangan remaja. Sehingga dari latar belakang tersebut diatas peneliti mengangkat sebuah judul tentang "Pelaksanaan Peraturan Daerah Kabupaten Jeneponto Nomor 8 Tahun 2006 Tentang Larangan Peredaran Minuman Beralkohol dan Pengawasannya".

\section{TINJAUAN PUSTAKA}

\section{Otonomi Daerah}

Istilah otonomi Daerah dan Desentralisasi sebenarnya mempunyai mempunyai pengertian yang berbeda. Istilah otonomi lebih cenderung berada dalam aspek politik kekuasaan Negara (political aspect), sedangkan desentralisasi lebih cenderung pada aspek administrasi (administrative aspect). Sebaliknya jika di lihat dari sharing of power (pembagian kekuasaan) kedua istilah tersebut mempunyai keterkaitan yang erat, dan tidak dapat di pisahkan. Artinya, jika berbicara mengenai otonomi daerah, tentu akan menyangkut pula pada pembicaraan seberapa besar wewenang untuk menyelenggarakan urusan pemerintahan yang telah di berikan sebagai wewenang daerah, demikian juga sebaliknya.

Syarief saleh mengatakan otonomi itu sebagai hak mengatur dan memerintah daerah sendiri. Atas inisiatif dan kemauan sendiri, dimana hak tersebut diperoleh pemerintah pusat. Wayong mengemukakan bahwa otonomi daerah itu adalah kebebasan untuk memilihara dan memajukan kepentingan khusus daerah, dengan keuangan sendiri. Sedangkan menurut Sugeng Istanto menyatakan bahwa otonomi di artikan sebagai hak atau wewenang untuk mengatur dan mengurus rumah tangga daerah.

Berangkat dari hal tersebut maka inti dari pelaksanaan otonomi daerah adalah terdapatnya keluasan pemerintah daerah (discretionary power) untuk menyelenggarakan pemerintahan sendiri atas dasar prakarsa, kreativitas dan peran serta aktif masyarakat dalam rangka mengembangkan dan memajukan daerahnya. Di sini masyarakat tidak saja dapat menentukan nasibnya sendiri melalui pemberdayaan masyarakat, melainkan yang utama adalah berupaya untuk memperbaiki nasibnya sendiri. Ada beberapa faktor yang mempengaruhi pelaksanaan otonomi daerah yaitu:
a. Manusia sebagai pelaksana
b. Keuangan daerah
c. Peralatan
d. Organisasi dan manajemen

Tujuan utama dikeluarkannya kebijakan otonomi daerah antara lain adalah membebaskan pemerintah pusat dari bebanbeban yang tidak perlu dalam menangani urusan daerah. Dengan demikian pusat berkesempatan mempelajari, memahami, merespon berbagai kecenderungan global dan mengambil manfaat daripadanya. Pada saat yang sama pemerintah pusat diharapkan lebih mampu berkonsentrasi pada perumusan kebijakan makro (luas atau yang bersifat umum dan mendasar) nasional yang bersifat strategis. Di lain pihak, dengan desentralisasi daerah akan mengalami proses pemberdayaan yang optimal. Kemampuan prakarsa dan kreativitas pemerintah daerah akan terpacu, sehingga kemampuannya dalam mengatasi berbagai masalah yang terjadi di daerah akan semakinkuat.

Adapun tujuan pemberian otonomi kepada daerah adalah sebagai berikut:

a. Peningkatan pelayanan dan kesejahteraan masyarakat yang semakin baik

b. Pengembangan kehidupan demokrasi

c. Keadilan

d. Pemerataan

e. Pemeliharaan hubungan yang serasi antara pusat dan daerah serta antar daerah dalam rangka keutuhan NKRI

f. Mendorong untuk memberdayakan masyarakat

g. Menumbuhkan prakarsa dan kreativitas, meningkatkan peran serta, 
mengembangkan peran dan fungsi Dewan Perwakilan Rakyat Daerah.

\section{Konsep Peraturan Daerah}

Menurut Undang - Undang Nomor 10

Tahun 2004 tentang Pembentukan Peraturan Daerah Perundang - undangan yang dimaksud dengan Peraturan Daerah (Perda) adalah peraturan perundang - undangan yang di bentuk oleh Dewan Perwakilan Rakyat Daerah dengan persetujuan bersama Kepala Daerah. Definisi lain adalah peraturan perundang undangan yang di bentuk bersama oleh Dewan Perwakilan Rakyat Daerah baik di provinsi maupun di Kabupaten/Kota.

Dalam penjelasan umum Undang undang Nomor 32 Tahun 2004 Tentang Pemerintahan Daerah juga berkaitan dengan (7). Peraturan Daerah dan Peraturan Kepala Daerah diatur,"penyelenggaraan pemerintahan daerah dalam melaksanakan tugas, wewenang, kewajiban dan tanggung jawabnya serta atas kuasa peraturan perundang - undangan yang lebih tinggi dapat menetapkan kebijakan daerah yang di rumuskan antara lain dalam peraturan daerah, peraturan kepala daerah, dan ketentuan daerah lainnya. Kebijakan daerah yang di maksud tidak boleh bertentangan dengan peraturan perundang - undangan yang lebih tinggi (Lex Superiori de rogat Lex Inferiori) dan kepentingan umum serta peraturan daerah lain. Peraturan daerah di buat oleh DPRD bersama - sama pemerintah daerah, artinya prakarsa dapat berhasil dari DPRD maupun dari Pemerintah Daerah. Khusus peraturan daerah tentang APBD rancangannya disiapkan oleh Pemerintah Daerah yang telah mencakup keuangan DPRD, untuk di bahas bersama DPRD. Peraturan Daerah dan ketentuan daerah lainnya yang bersifat mengatur diundangkan dengan menempatkannya dalam Lembaran Daerah. Peraturan Daerah tertentu yang mengatur pajak daerah, retribusi daerah, APBD, perubahan APBD, dan tata ruang berlakunya setelah melalui tahapan evaluasi oleh pemerintah. Hal itu di tempuh dengan pertimbangan antara lain untuk melindungi kepentingan umum, menyelaraskan dan menyesuaikan dengan peraturan perundang undangan yang lebih tiinggi dan/atau peraturan daerah lainnya, terutama peraturan daerah mengenai pajak daerah dan retribusi daerah."

Dalam Undang - Undang Nomor 32 Tahun 2004 tentang Pemerintahan Daerah (UU Pemda), peraturan daerah di bentuk dalam rangka otonomi daerah Provinsi/Kabupaten/Kota dan tugas pembantuan serta merupakan penjabaran lebih lanjut dari peraturan perundang - undangan yang lebih tinggi dengan memperhatikan ciri khas masing - masing daerah. Sesuai ketentuan Pasal 12 Undang - undang Nomor 10 Tahun 2004 tentang Pembentukan Peraturan Perundang - undangan, materi muatan Perda adalah seluruh materi muatan dalam rangka penyelenggaraan otonomi daerah dan tugas pembantuan dan menampung kondisi khusus daerah serta penjabaran lebih lanjut Peraturan Perundang - undangan yang lebih tinggi. Rancangan peraturan daerah dapat berasal dari Dewan Perwakilan Rakyat Daerah ( DPRD ), Gubernur atau Bupati/Walikota. Apabila dalam satu kali masa sidang Gubernur atau Bupati/Walikota dan DPRD menyampaikan rancangan Perda dengan materi yang sama, maka yang di bahas adalah rancangan Perda yang di sampaikan oleh DP sedangkan rancangan Perda yang di sampaikan oleh Gubernur atau Bupati/Walikota dipergunakan sebagai bahan persandingan. Program penyusunan Perda dilakukan dalam satu Program Legislasi Daerah, sehingga diharapkan tidak terjadi tumpan tindih dalam penyiapan satu materi Perda

Ada berbagai jenis Perda yang di tetapkan oleh Pemerintah Daerah Kabupaten Kota dan Provinsi antara lain:
a. Pajak Daerah
b. Retribusi Daerah
c. Tata Ruang Wilayah Daerah
d. APBD
e. Rencana Program Jangka Menengah Daerh
f. Perangkat Daerah
g. Pemerintahan Desa
h. Pengaturan umum lainnya
Dalam pasal 7 ayat 1 Undang - undang Nomor 12 Tahun 2011 Tentang Pembentukan Peraturan Perundang - undangan mengatur," jenis dan hirarki peraturan perundang - 
undangan terdiri atas: a. Undang - Undang Dasar Negara Republik Indonesia tahun 1945;

b. ketetapan Majelis Permusyawaratan perwakilan rakyat

c. undang - undang

d. peraturan pemerintah

e. peraturan presiden

f. peraturan daerah provinsi dan;

g. peraturan daerah kabupaten/kota

Dalam pasal ini tertera dengan jelas bahwa peraturan daerah merupakan peraturan perundang - undangan. Perlu di ketahui bahwa peraturan perundang - undangan adalah segala peraturan Negara yang merupakan hasil pembentukan peraturan - peraturan baik di tingkat pusat maupun daerah.

Peraturan Daerah adalah salah satu bentuk peraturan pelaksana undang - undang. Pada pokoknya, kewenangannya mengatur bersumber dari kewenangan yang di tentukan oleh pembentuk undang - undang. Akan tetapi, dalam hal - hal tertentu, peraturan daerah juga dapat mengatur sendiri hal - hal tertentu, peraturan daerah juga dapat mengatur sendiri whal - hal yang meskipun tidak didelegasikan secara eksplisit kewenangannya oleh undang undang, tetapi dianggap perlu diatur oleh daerah untuk melaksanakan otonomi daerah yang seluas luasnya sebagaimana di maksud oleh pasal 18 ayat (3) dan (4) UUD 1945. Bahkan, dalam peraturan daerah juga dapat di muat mengenai ketentuan pidana seperti halnya dalam undang - undang. Dalam pasal 14 UU No. 10 Tahun 2004 di tentukan, "materi muatan mengenai ketentuan pidana hanya dapat dimuat dalam Undang - undang dan Peraturan Daerah".

Peraturan Daerah, baik peraturan daerah provinsi, kabupaten, maupun peraturan daerah kota di undangkan dalam lembaran daerah; sedangkan Peraturan Gubernur, Peraturan Bupati / Walikota, atau peraturan lain di bawahnya dimuat dalam Berita Daerah. Pengundangan peraturan daerah dalam lembaran daerah dan Berita daerah dilaksanakan oleh sekretaris daerah. Selanjutnya, setelah di undangkan sebagaimana mestinya, peraturan daerah tersebut menurut pasal 52 wajib disebarluaskan.
Pemerintah daerah wajib menyebarluaskan peraturan yang telah di undangkan dalam lembaran daerah dan peraturan di bawahnya yang telah di undangkan dalam berita daerah. Untuk itu, kepala pemerintah daerah, yaitu gubernur, bupati,dan walikota harus melaksanakan kewajibannya itu dengan sungguh - sungguh dengan menyelenggarakan berbagai program penyebarluasan informasi dan pengetahuan hukum dalam lingkup wilayah tanggung jawabnya masing - masing.

Bahkan penyebarluasan informasi dan pengetahuan hukum itu sendiri harus pula di maknai sebagai tanggung jawab yang menyangkut tuntutan kebutuhan akan pendidikan, pemasyarakatan, dan pembudayaan hukum dalam arti yang lebih luas dan menyeluruh di setiap daerah, sehingga upaya mewujudkan cita Negara hukum, dimana sistem hukum dan konstitusi yang menjadi landasan bekerjanya sistem bernegara dapat berjalan dengan sebaik - baiknya di mana hukum dan keadilan benar - benar terwujud sebagaimana mestinya.

\section{Peraturan Daerah Kabupaten Jeneponto 8 Tahun 2006 Tentang Larangan Peredaran Minuman Beralkohol dan Pengawasannya.}

Dalam penyelenggaraan otonomi daerah, ada dua produk hukum yang dapat dibuat oleh suatu daerah, salah satunya adalah Peraturan Daerah. Kewenangan membuat peraturan daerah (Perda), merupakan wujud nyata pelaksanaan hak otonomi yang dimiliki oleh suatu daerah dan sebaliknya, peraturan daerah merupakan salah satu sarana dalam penyelenggaraan otonomi daerah. Perda ditetapkan oleh Kepala Daerah setelah mendapat persetujuan bersama DPRD, untuk penyelenggaraan otonomi yang dimiliki oleh provinsi /kabupaten/kota, serta tugas pembantuan. Perda pada dasarnya merupakan penjabaran lebih lanjut dari peraturan perundang-undangan yang lebih tinggi, dengan memperhatikan ciri khas masing-masing daerah. Perda yang dibuat oleh satu daerah tidak boleh bertentangan dengan kepentingan umum dan/ atau peraturan perundangundangan yang lebih tinggi,dan baru 
mempunyai kekuatan mengikat setelah diundangkan dengan dimuat dalam lembaran daerah.

Peraturan Daerah Kabupaten Jeneponto Nomor 8 tahun 2006 Tentang Larangan Peredaran Minuman Beralkohol dan Pengawasannya di tetapkan pada tanggal 20 Juni 2006 oleh Bapak Bupati H. Radjamilo. Adapun dasar pertimbangan dibentuknya ini yaitu bahwa dengan semakin meningkatnya tindak kejahatan sebagai akibat meminum minuman beralkohol yang dapat mengganggu ketentraman masyarakat perlu mengatur Larangan Peredaran Minuman Beralkohol dan Pengawasannya.

Peraturan Daerah ini terdiri dari 9 Bab dan 26 Pasal. Dan di harapkan dengan adanya Peraturan Daerah ini Peredaran Minuman Beralkohol dapat terkontrol dan menjaga ketentraman masyarakat. Sebagaimana dalam Pasal 2 ayat (1 dan 2) yang menyatakan bahwa: (1) Setiap orang atau badan dilarang melakukan peredaran minuman beralkohol dalam Daerah Kabupaten Jeneponto kecuali tempat lain yang ditentukan dengan izin Bupati;(2) Setiap orang dilarang mengkonsumsi minuman beralkohol dalam Daerah Kabupaten Jeneponto kecuali ditempat lain yang ditentukan dengan izin Bupati;

Dengan adanya Peraturan Daerah ini di harapkan peredaran minuman beralkohol tidak beredar secara liar di kalangan masyarakat sebagaimana dalam Pasal 8 ayat (1 dan 2 ) yang menyatakan bahwa: (1) hotel berbintang dan kawasan khusus sebagaimana dimaksud pada pasal 3 ayat (2) yang dapat diberi izin untuk mengedarkan minuman beralkohol harus jauh dari: a. tempat pemukiman, b. tempat tempat ibadah, c. tempat - tempat pendidikan, d. tempat - tempat perkantoran dan e. tempat tempat keramaian lainnya. (2) radius kejauhan ditetapkan 2000 meter dari tempat - tempat sebagaimana dimaksud pada ayat (1).

Keberadaan Peraturan ini di harapkan mampu mengurangi peredaran minuman beralkohol dengan melakukan razian secara rutin. Sebagaimana termuat dalam Pasal 9 ayat (1) bahwa: untuk mengantisipasi dan menanggulangi penyalahgunaan peredaran minuman beralkohol, Pemerintah Kabupaten
Jeneponto wajib mengadakan razia secara terprogram dan berkelanjutan; agar pasal tersebut diatas dapat terlaksana dengan baik maka perlu dilakukan pembinaan oleh Pemerintah Daerah sebagaimana dalam Pasal 13 ayat (1 dan 3 ) yang menyatakan bahwa: (1) Pemerintah Daerah wajib melakukan pembinaan dalam rangka penanggulangan bahaya mengkonsumsi minuman beralkohol yang mengandung unsure memabukkan; (3) pembinaan sebagaimana dimaksud pada ayat (1) dilakukan dalam bentuk antara lain: a. penyuluhan mengenai bahaya mengkonsumsi minuman beralkohol, b. pembinaan terhadap pengedar yang memperoleh izin sebagaimana dimaksud pada pasal 5 .

Diharapkan dengan adanya peraturan daerah ini dapat berjalan efektif sehingga keamanan dan ketentraman dalam masyarakat dapat terjaga dan penerapan peraturan daerah sangat di pengaruhi oleh berat ringannya sanksi yang di berikan bagi siapa saja yang melanggar aturan tersebut.

\section{Hakekat Minuman Keras dan Larangannya \\ Minuman Keras atau di singkat miras} adalah satu jenis minuman yang banyak digemari orang yang bilamana orang sudah terbiasa akan menjadi ketagihan dan bahkan dapat di buat mabuk karenanya. Minuman keras atau miras pada dasarnya adalah minuman yang mengandung alkohol baik berkadar tinggi maupun rendah.

Sehubungan dengan hal di atas, Dadang Hawari menjelaskan bahwa: " Miras atau minuman keras adalah jenis minuman yang mengandung alkohol di dalamnya".

Dari uraian diatas dapat dikemukakan bahwa minuman keras adalah minuman beralkohol yang tidak di lihat dari kadar alkoholnya baik banyak maupun sedikit. Sehingga tinggi atau rendahnya kadar alkoholnya suatu minuman tetap di anggap sebagai minuman keras.

Senada dengan hal diatas, maka pengertian minuman keras atau minuman beralkohol menurut Keputusan Menteri Perindustrian dan perdagangan Republik 
Indonesia No.359/MPP/Kep/10/1997 Bab 1 pasal 1 nomor 1 menyatakan :

" Minuman beralkohol adalah minuman yang mengandung ethanol yang diproses dari bahan hasil pertanian yang mengandung karbohidrat dengan cara fermentasi dan destilasi atau fermentasi tanpa destilasi, baik dengan cara memberikan perlakuan terlebih dahulu atau tidak, maupun yang diproses dengan cara mencampur konsetrat dengan ethanol atau dengan cara pengenceran minuman dengan ethanol".

Menurut Joewana tentang minum minuman keras dan penyalahgunaan obat obatan yang di lakukan oleh remaja/orang dewasa adalah di motivasi oleh:

1) Untuk mengatasi perasaan gelisah, tegang dan sedih

2) Untuk memenuhi rasa ingin tahunya

3) Untuk memperoleh pengalaman baru

4) Untuk hiburan, iseng, mengatasi rasa bosan dan jenuh

5) Untuk menunjukkan dirinya sudah dewasa

6) Untuk memperlihatkan sikap menentang orang tua

7) Untuk memperlancar pergaulan agar dapat di terima dalam suatu kelompok alkohol termasuk zat adiktif, bahwa zat ini dapat menimbulkan adikasi yaitu ketagihan dan ketergantungan. Mengkonsumsi minuman keras dapat menimbulkan gangguan mental organic ( OMG ) yaitu ganggaun dalam fungsi berfikir, perasaan dan perilaku.

8) Gangguan mental organik ini disebabkan adanya reaksi langsung dari alkohol ini, maka orang yang meminum minuman keras tersebut lama - kelamaan tanpa ia sadari akan menambah takaran / dosis sampai pada dosis keracunan atau mabuk.

9) Dengan adanya gejala putus sindrom alkohol tersebut diatas yang di rasakan sebagai suatu penderitaan, maka orang itu berupaya untuk minum lagi dengan takaran yang lebih tinggi, demikianlah seterusnya.
10) Pada dasarnya minuman keras adalah suatu jenis minuman yang terlarang. Yang di larang oleh agama dan pemerintah.

11) Dalam kaitannya juga dengan hal tersebut di atas Dadang Hawari juga mengemukakan bahwa: "Majelis Ulama Indonesia ( MUI ) sudah mengeluarkan fatwa bahwa setetes alkohol saja dalam minuman hukumnya haram".

\section{Faktor - Faktor yang Mempengaruhi Penegakan Hukum}

Penegakan hukum sebagai suatu proses, pada hakikatnya merupakan penerapan diskresi yang menyangkut membuat keputusan yang tidak secara ketat diatur oleh kaidah hukum, akan tetapi mempunyai unsur penilaian pribadi ( Wayne La Favre 1964 ). Dengan mengutip pendapat Roscoe Pound, maka La Favre menyatakan, bahwa pada hakikatnya diskresi berada di antara hukum dan moral ( etika dalam arti sempit ). bahwa masalah pokok penegakan hukum sebenarnya terletak pada faktor - faktor yang mungkin mempengaruhinya. Faktor - faktor tersebut mempunyai arti yang netral, sehingga dampak positif atau negatifnya terletak pada isi faktor faktor tersebut. Faktor - faktor tersebut, adalah sebagai berikut:

1. Faktor hukumnya sendiri, yang di dalam tulisan ini akan dibatasi pada undang undang saja

2. Faktor penegak hukum, yakni pihak pihak yang membentuk maupun menerapkan hukum

3. Faktor sarana atau fasilitas yang mendukung penegakan hukum

4. Faktor masyarakat, yakni lingkungan di mana hukum tersebut berlaku atau diterapkan

5. Faktor kebudayaan, yakni sebagai hasil karya, cipta, dan rasa yang didasarkan pada karsa manusia di dalam pergaulan hidup.

\section{Pengawasan}

Pengawasan merupakan salah satu cara untuk membangun dan menjaga legitimasi warga masyarakat terhadap kinerja 
pemerintahan dengan menciptakan suatu sistem pengawasan yang efektif, baik pengawasan intern (internal control) maupun pengawasan ekstern (external control). Di samping mendorong adanya pengawasan masyarakat (social control). Sasaran pengawasan adalah temuan yang menyatakan terjadinya penyimpangan atas rencana atau target. Sementara itu, tindakan yang dapat dilakukan adalah:

1. Mengarahkan atau merekomendasikan perbaikan;

2. Menyarankan agar ditekan adanya pemborosan;

3. Mengoptimalkan pekerjaan untuk mencapai sasaran rencana

Pengertian pengawasan atas penyelenggaraan pemerintah daerah sesuai dengan pasal 1 Peraturan Pemerintah No. 79 Tahun 2005 tentang Pedoman Pembinaan dan Pengawasan Penyelenggaraan Pemerintahan Daerah menyatakan bahwa:

"Pengawasan atas penyelenggaraan Pemerintahan Daerah adalah proses kegiatan yang ditujukan untuk menjamin agar Pemerintahan Daerah berjalan secara efisien dan efektif sesuai dengan rencana dan ketentuan peraturan perundang-undangan.”

\section{METODE PENELITIAN}

Penelitian ini adalah penelitian deskriptif kualitatif sebab penelitian deskriptif kualitatif ini menekankan pada pembangunan naratif atau deskripsi tekstual atas fenomena yang diteliti yang bertujuan untuk mendapatkan pemahaman tentang kenyataan melalui proses berpikir induktif.

Dalam penelitian ini sumber data primer yang menjadi informannya adalah Satuan Polisi Pamong Praja, Pihak Kepolisian Sektor Binamu, Camat Binamu dan Masyarakat Kecamatan Binamu.

Prosedur pengumpulan data yang digunakan dalam penelitian ini dalah wawancara dan dokumentasi. Wawancara adalah suatu percakapan yang diarahkan pada suatu masalah tertentu dan merupakan proses tanya jawab lisan dimana satu orang atau lebih berhadapan secara fisik. Yang menjadi informan dalam hal ini adalah Satuan Polisi Pamong Praja, Pihak Kepolisian Sektor Binamu, Camat Binamu dan Masyarakat Kecamatan Binamu. Sedangkan Dokumentasi diartikan sebagai upaya untuk memperoleh data dan informasi berupa catatan tertulis/gambar yang tersimpan berkaitan dengan masalah yang diteliti. Dokumen merupakan fakta dan data tersimpan dalam berbagai bahan yang berbentuk dokumentasi.

Penelitian ini bersifat deskriptif analisis data kualitatif yang dilakukan secara interaktif dan berlangsung terus menerus pada setiap tahapan penelitian sampai tuntas dan datanya sampai jenuh.

\section{PEMBAHASAN}

Berdasarkan hasil penelitian yang dilakukan menunjukkan bahwa Peraturan Daerah Kabupaten Jeneponto Nomor 8 Tahun 2006 belum berjalan secara efektif. Hal ini dikerenakan beberapa Pasal dalam Perda tersebut yang belum terlaksana dengan baik. Adapun yang menjadi faktor pendukung Perda tersebut adalah adanya partisipasi tokoh agama dan masyarakat, kerjasama antar aparat pemerintah, sedangkan beberapa alasan yang menyebabkan kurang berjalannya Perda tersebut yaitu karena faktor kesadaran masyarakat, faktor sosialisasi, faktor pemberian sanksi, faktor kebiasaan serta tindak lanjut dari pelanggaran Perda No. 8 tahun 2006 masih dalam tahap non yuspisial yaitu tidak adanya penyelidikan dan penyidikan di bagian Satuan Polisi Pamong Praja. Berikut beberapa faktor pendukung dalam pelaksanaan Perda No. 8 tahun 2006

Adanya partisipasi dari tokoh agama dan masyarakat membantu dalam pelaksanaan Perda No. 8 tahun 2006, dimana masyarakat yang memiliki pengetahuan yang lebih dari masyarakat yang lain dapat mengingatkan kepada masyarakat yang kurang memliki pengetahuan akan bahaya dari mengkonsumsi minuman beralkohol sehingga dapat membantu mengurangi peredaran minuman beralkohol meskipun hal tersebut belum bisa mengatasi peredaran minuman beralkohol di kalangan masyarakat secara maksimal. 
Terjalinnya kerjasama antar aparat pemerintah terkait dapat meningkatkan penegakan pelaksanaan perda sehingga keamanan dan ketertiban dalam masyarakat dapat terjaga meskipun hal ini belum mampu mengatasi peredaran minuman beralkohol yang ada di masyarakat karena kurangnya koordinasi yang baik. Sedangkan yang menjadi alasan faktor penghambat dalam pelaksanaan Perda No. 8 tahun 2006 yaitu:

Kurangnya tingkat kesadaran masyarakat dalam mematuhi peraturan yang ada menjadi penghambat dalam melaksanakan Perda No 8 tahun 2006. Hal ini disebabakan karena ketidaktahuan masyarakat akan keberadaan Perda tersebut sehingga masyarakat kurang paham atau karena memang masyarakat tidak mau peduli terhadap aturan yang berlaku.

Alasan lain tidak terlaksananya Perda No. 8 tahun 2006 adalah kurangnya sosialisasi yang dilakukan oleh aparat pemerintah untuk memberikan informasi kepada masyarakat akan keberadaan Perda ini sehingga menyebabkan sebagian masyarakat tidak mengetahui keberadaan Perda tersebut padahal keberadaan Perda ini sudah lama ada. Sosialisasi hukum bertujuan agar warga masyarakat mengetahui dan memahami hukum-hukum tertentu.Selanjutnya pengetahuan hukum yang dimiliki masyarakat akan mempengaruhi kesadaran hukum mereka.

Selain sosialisasi yang kurang faktor pemberian sanksi yang tidak tegas juga menjadi penghambat dalam Pelaksanaan Perda No. 8 tahun 2006 dimana para penjual maupun peminum yang didapati menjual atau mengkonsumsi minuman beralkohol hanya di beri surat teguran/peringatan bagi penjual dan untuk peminum hanya membuat surat pernyataan bahwa mereka tidak akan mengulangi perbuatannya. Hal ini tentu tidak sesuai dengan ketentuan yang tercantum dalam Pasal 22 ayat (1) dimana dalam Pasal tersebut di jelaskan dengan tegas bahwa: Pelanggaran terhadap Peraturan Daerah ini diancam pidana kurungan 6 bulan dan denda sebesar Rp. 5 . 000.000 juta. Sehingga tidak memberikan efek jerah.

Penyebab lainnya adalah faktor kebiasaan mengkonsumsi minuman beralkohol terutama minuman beralkohol jenis ballo (tuak) sudah menjadi kebiasaan bagi sebagian masyarakat sehingga sulit untuk diatasi. Karena bagi masyarakat yang sudah biasa mengkonsumsi minuman beralkohol jenis ballo (tuak) kemudian tidak meminum dalam satu hari mereka merasa ada sesuatu yang hilang dan merasa gelisah.

Selain faktor yang sudah disebutkan diatas penyebab yang lain adalah tindak lanjut dari pelanggaran Peraturan Daerah Nomor 8 tahun 2006 masih dalam tahap non yuspisial yaitu tidak adanya penyelidikan dan penyidikan di bagian Satuan Polisi Pamong Praja. Tidak adanya tindak lanjut dari pihak satuan polisi pamong praja terhadap orang yang melanggar peraturan daerah no. 8 tahun 2006 menyebabkan mereka tidak bisa mengambil tindakan yang lebih jauh untuk melakukan penyelidikan kepada masyarakat karena bukan kewenangannya sehingga menjadi salah satu penghambat dalam pelaksanaan perda tersebut.

\section{PENUTUP}

\section{Kesimpulan}

Berdasarkan uraian dan hasil penelitian yang telah di jelaskan pada bab sebelumnya maka penulis menarik kesimpulan sesuai dengan permasalahan yang diteliti yaitu Pelaksanaan Peraturan Daerah No 08 Tahun 2006 Tentang Larangan Peredaran Minuman Beralkohol dan Pengawasannya adalah sebagai berikut :

1. Pelaksanaan Perda No 08 Tahun 2006 Tentang Larangan Peredaran Minuman Beralkohol dan Pengawasannya belum berjalan dengan efektif. Hal ini disebabkan karena masih banyaknya minuman beralkohol yang beredar di masyarakat yang bisa di dapat di toko - toko dan rumah warga serta kurangnya pengetahuan masyarakat tentang Perda tersebut.

2. faktor pendukung dan penghambat dari pelaksanaan peraturan daerah no. 8 tahun 2006.

a. Faktor Pendukung

1.Partisipasi tokoh agama dan masyarakat 
2. Kerjasama antar aparat pemerintah

b. Faktor Penghambat

1. Faktor Kesadaran yaitu kurangnya kesadaran masyarakat untuk mematuhi peraturan yang ada

2. Faktor Sosialisasi yaitu kurangnya sosialisai yang dilakukan oleh aparat pemerintah menyebabkan Perda No. 8 tahun 2006 tentang Larangan Peredaran Minuman Beralkohol dan Pengawasannya belum efektif.

3. Faktor Pemberian Sanksi kepada orang yang melanggar Perda No. 8 tahun 2006 tidak di berlakukan secara tegas.

4. Faktor Kebiasaan sudah menjadi kebiasaan bagi sebagian masyarakat untuk mengkonsuumsi minuman beralkohol.

5. Tindak lanjut dari Pelanggaran Perda No. 8 tahun 2006 masih dalam tahap non yuspisial yaitu tidak adanya penyelidikan dan penyidikan di bagian satuan polisi pamong praja.

\section{Saran}

Adapun saran dalam penelitian ini adalah bagi pemerintah dalam membuat atau merancang Peraturan Daerah hendaknya memperhatikan asas - asas pembuatan Perda yang baik, serta sesuai dengan situasi dan kondisi yang terjadi dalam kehidupan masyarakat dan lebih meningkatkan lagi penegakan dari Peraturan Daerah Nomor 8 tahun 2006 dengan melakukan sosialisasi secara berkelanjutan meskipun keberadaannya sudah lama serta melakukan penyuluhan oleh pihak - pihak terkait dalam upaya meningkatkan kesadaran hukum kepada masyarakat.

\section{DAFTAR PUSTAKA}

Bambang Yudoyono. 2001. Otonomi Daerah Desentralisasi dan Pengembangan SDM Aparatur PEMDA dan Anggota DPRD. Jakarta: Pustaka Sinar Harapan.

Barda Nawawi Arief. 2001. Masalah Penegakan Hukum \& Kebijakan Penanggulangan Kejahatan. Bandung: PT.Citra Aditya Bakti.
Basrowi dan Suwandi. 2008. Memahami Penelitian Kualitatif. Jakarta:

Rineka Cipta

Imam Gunawan. 2013. Metode kualitatif teori dan praktik. Malang: Bumi

Aksara.

Dadang Hawari. 2006. Penyalahgunaan dan Ketergantungan NAZA
(Narkotika,
Alkohol \& Zat

Adiktif). Jakarta: Balai Penerbit FKUI.

Jimly Asshidiqie. 2011. Perihal Undang undang. Jakarta: Rajawali Pers.

Josef Riwu Kaho. 2001. Prospek Otonomi Daerah di Negara Republik

Indonesia. Jakarta: Rajawali Pers.

Ni'matul Huda. 2005. Hukum Tata Negara Indonesia, Jakarta: Rajawali Pers.

Sarman, Mohammad Taufik Makaraso.2011.

Hukum Pemerintahan Daerah di Indonesia. Jakarta: Rineka Cipta.

Siswanto Sunarno. 2005 Hukum Pemerintahan Daerah di Indonesia. Jakarta:

Sinar Grafika.

Soerjono Soekanto. 1993 Faktor - Faktor yang Mempengaruhi Penegakan

Hukum. Jakarta: Rajawali Pers.

Solly Lubis . 2009. Ilmu Pengetahuan Perundang - undangan. Bandung:

Mandar Maju

Sugiyono. 2015. Metode Penelitian Kuantitatif, Kualitatif, dan $R \& D$.

Bandung: Alfabeta

Undang - Undang Nomor 12 Tahun 2011

Tentang Pembentukan Peraturan

Perundang - undangan.

Peraturan Daerah Kabupaten Jeneponto Nomor 8 Tahun 2006 Tentang

Larangan Peredaran Minuman Beralkohol dan Pengawasannya.

http://elib.unikom.ac.id/files/disk1/683/jbptunik ompp-gdl-anjaswigun34101-9- unikom ai.pdf, kamis, 18 februari, 2016, pukul 22:15.

https://asefts63.wordpress.com/materipelajaran/pkn-kls-9/pelaksanaan-otonomidaerah/ diakses pada tanggal 12 april 2016, pukul 10:48 